Article

\title{
Residential Segregation and Unequal Access to Schools
}

\author{
Jaap Nieuwenhuis * and Jiayi Xu \\ Department of Sociology, Zhejiang University, 310058 Hangzhou, China; E-Mails: jaap_nieuwenhuis@zju.edu.cn (J.N.), \\ 21922015@zju.edu.cn (J.X.) \\ * Corresponding author
}

Submitted: 25 August 2020 | Accepted: 9 December 2020 | Published: 13 May 2021

\begin{abstract}
Socio-spatial inequality and school inequality are strongly related. Where people live affects the opportunities individuals have in life, such as the opportunity to send your children to a good school. The level of urbanisation is related to the number of options people have to choose good schools, so more urbanised areas likely offer more options for good schools. However, the families that can choose good schools are likely families with high income or education levels. Data for this study come from two waves of the Taiwan Youth Project $(\mathrm{N}=2,893)$, which consists of two cohorts of students from 162 classrooms in 40 junior high schools in northern Taiwan. When school quality is proxied by socioeconomic status (SES), the results show that, in general, students from the most urbanised areas, wealthier parents, and higher-educated parents, are more likely to go to higher SES schools. However, the strongest effects are for higher income and higher-educated parents in the most urbanised areas. This suggests that in the most urbanised areas, families have the most options regarding school choice, and richer and more educated families are better able to circumvent school catchment areas, either because they can afford an address in a better catchment area or because they understand the importance of school choice.
\end{abstract}

\section{Keywords}

catchment areas; parental socio-economic status; school quality; segregation; urbanisation

\section{Issue}

This article is part of the issue "Vicious Circle of Segregation: Understanding the Connectedness of Spatial Inequality across Generations and Life Domains" edited by Tiit Tammaru (University of Tartu, Estonia), Siiri Silm (University of Tartu, Estonia), Frank Witlox (Ghent University, Belgium), Maarten van Ham (Delft University of Technology, The Netherlands) and Madli-Johanna Maidla (University of Tartu, Estonia).

(C) 2021 by the authors; licensee Cogitatio (Lisbon, Portugal). This article is licensed under a Creative Commons Attribution 4.0 International License (CC BY).

\section{Introduction}

School quality plays a crucial role in chances for a good education. Good schools provide students with higher learning outcomes and nonmaterial resources, such as social and cultural capital to succeed in a work environment (Bourdieu, 1977; Lareau, 1987). Education is known as the most effective path to upward social mobility for disadvantaged children by creating an equitable distribution of learning outcomes (Downey \& Condron, 2016). However, educational inequality has persisted over time in many countries and been widely discussed again since the neoliberal education reforms (Alon, 2009; Tam \& Jiang, 2014; Yang, Huang, \& Liu, 2014). In this study, we focus on the case of Taiwan, where educational inequality is also emphasised as a concern by several studies (L.-J. Chen, 1993; L.-J. Chen \& Chen, 2009; Y. G. Chen, 2001; Mao, 2015), but is understudied when it comes to spatial processes (Nieuwenhuis, 2020; Nieuwenhuis \& Hooimeijer, 2016).

School quality can be operationalised in different ways, all with their own limitations. We suggest that the idea of school quality is partly socially constructed through parental perceptions. Certain schools are perceived to be of higher quality than others and parents use their resources to ensure their child's admission to those schools. This will ultimately lead to a sorting of children from different socioeconomic backgrounds into 
different schools, with schools that are perceived as highquality having a, on average, higher socioeconomic status (SES) population than schools that are not perceived as high quality. Therefore, school quality is proxied with average school income. Schools' quality has more often been linked to the SES of its population (Condron \& Roscigno, 2003; Perry \& McConney, 2010), and higherSES schools have been shown to positively impact students' educational achievement (Nieuwenhuis, 2018; Portes \& MacLeod, 1996). Schools with a higher SES population provide more social and cultural capital, which can further benefit students' achievement (Cheadle \& Amato, 2011; Lareau, 1987). When higher parental SES is reflected in school expenditure, higher-SES schools can afford better teachers, activities, and facilities (Elliott, 1998; Greenwald, Hedges, \& Laine, 1996; Hochschild \& Scovronick, 2003), as well as enhance the teacherstudent ratio (Wenglinsky, 1997). Although most public primary and secondary schools in many areas receive equal government funding (Butler \& van Zanten, 2007), good schools are unequally spatially distributed (Oberti, 2007; Wilson \& Bridge, 2019). Generally, more developed urban areas have more higher-SES families and more educational resources, so schools in urbanised areas have higher-SES populations and are often of better quality than in less urbanised areas (L.-J. Chen \& Chen, 2009; Owens \& Candipan, 2019; Parsons, Chalkley, \& Jones, 2000). Thus, urban children are likely to have better access to good schools.

Also within urban areas, the distribution and access opportunities of good schools are unequal because of school segregation, which is strongly connected to residential segregation (Bernelius \& Vaattovaara, 2016; Oberti, 2007; Taylor \& Gorard, 2001). Many countries set school catchment areas that link the place of residence to a selection of nearby schools available to children in that area (e.g.: in the UK, see Mayet, 1996; Parsons et al., 2000; in Germany, see Noreisch, 2007; in France, see Oberti \& Savina, 2019; in Australia, see Rowe \& Lubienski, 2017; in China, see Wen, Xiao, \& Zhang, 2017; Wu, 2012). Because of residential segregation by SES (Nieuwenhuis, Tammaru, van Ham, Hedman, \& Manley, 2020), some school catchment areas are wealthier than others and consequently have schools with higher average income levels. When, as described above, perceived school quality is what attracts high-income families to certain catchment areas, a correlation between school quality and the school population's income is suggested. For example, in the US, the quality of public schools was found to be shaped by the amount of wealth in a school district (Kozol, 1991; Slavin, 1999).

Family background is considered a strong predictor of educational differentiation (Marjoribanks, 1979; Nieuwenhuis, Hooimeijer, van Dorsselaer, \& Vollebergh, 2013). Studies show that parental income and education influence children's ability to do well in education (Cheadle \& Amato, 2011; Lareau, 1987). Some argue that working-class parents with low income and edu- cational levels pay less attention to school choice and long term educational strategies (Ball, 2002). Others believe that although parents of each class have the same educational expectations for children, they have vastly different abilities and economic resources to attain them (Chin \& Phillips, 2004; Votruba-Drzal, 2003). Highincome parents can afford houses in urban areas with better schools, and higher-educated parents may be better equipped with knowledge about good schools (Webber \& Butler, 2007). Therefore, to understand the relation between parents' income and education and school quality in areas with different levels of urbanisation, we examine the interaction between urbanisation and parental SES in Taiwan. This will shed light on whether high-SES parents are better able to exploit the opportunities of urbanised areas than low-SES parents. In sum, our research question is: How are urbanisation and the interrelation between urbanisation and parental socioeconomic background related to students' differential access to schools? By studying the Taiwanese case, we include an East Asian perspective to the mostly Western-based body of literature.

\section{Factors Shaping Access Opportunities to Good Schools}

Both urbanisation (Parsons et al., 2000) and family SES (Cheadle \& Amato, 2011; Marjoribanks, 1979) make differences to children's chances for good schooling, and the two factors are intertwined as family SES tends to be related to spatial residential choice (Nieuwenhuis \& Hooimeijer, 2016). High-SES families tend to aggregate in urban areas where dense population and developed economies give rise to more well-paid, high-skilled jobs (Hacker, Klaesson, Pettersson, \& Sjölander, 2013). Besides, due to residential sorting based on income, not only between areas of different levels of urbanisation but also within areas, the spatial distribution of households with different SES is uneven (Nieuwenhuis et al., 2020; Oberti \& Savina, 2019). Much of the existing literature investigates access opportunities to good schools in terms of urbanisation and family SES separately, but their combined impact lacks sufficient exploration. We will, therefore, review the existing research from each of these two perspectives first and then propose our hypotheses.

\subsection{Urbanisation and Residential Segregation Causing Educational Inequality}

Education is socio-geographically unequal because economically developed urban areas tend to have more resources for infrastructure like schools (Logan, Minca, \& Adar, 2012; Roscigno, Tomaskovic-Devey, \& Crowley, 2006). Take the US as an example, poorly performing schools are located in the most disadvantaged rural areas that suffer high poverty rates (Lichter \& Brown, 2011; Lichter, Cornwell, \& Eggebeen, 1993). Noreisch (2007) 
reported that in Germany, there are far more school options in urban areas than in rural areas. In some places (e.g., in Taiwan), the central government provides disadvantaged public schools with subsidies according to a uniform national standard, but studies show that educational funds are still unequal (L.-J. Chen, 1993; L.-J. Chen \& Chen, 2013). Also, many countries allow private schools to encourage competition for quality development in public schools (Broccolichi \& van Zanten, 2000; Lubienski, 2005; Rowe \& Lubienski, 2017). These private schools reinforce the educationally advantaged position of urbanised areas. For example, in Chile, private schools located closer to the city centre have better teachers, student-teacher ratio, and educational test results than more peripherally located schools (De la Fuente, Rojas, Salado, Carrasco, \& Neutens, 2013). In sum, urbanised areas have a greater variety of schools both in quality and quantity than less urbanised areas, suggesting between-area inequality in opportunities for good schooling.

Schools are also unequally distributed within urbanised areas. Generally, the best performing and most attractive schools are concentrated in the most advantaged urban neighbourhoods, while the less developed schools are located in mostly working-class neighbourhoods (Oberti, 2007). This is partly because high- and low-income families cluster in separate neighbourhoods within the city, which appears as economic residential segregation (Nieuwenhuis et al., 2020). Residential segregation and school segregation are thought to be mutually reinforcing factors (Bernelius \& Vaattovaara, 2016; Frankenberg, 2013; Taylor \& Gorard, 2001; Waslander \& Thrupp, 1995). High-performing schools are likely to be located in affluent neighbourhoods (Oberti \& Savina, 2019), where there are school catchment areas with higher levels of income (Rowe \& Lubienski, 2017). The amount of wealth in a school catchment area shapes its school's quality (Kozol, 1991; Slavin, 1999). Consequently, the housing market around popular schools will be hot and thus hard for low-income parents to afford, further restraining their school choices. The more wealthy parents try to move into areas with desirable schools, the more expensive popular areas become (Butler \& van Zanten, 2007; Wen et al., 2017), resulting in expensive gentrified areas only available to a wealthy few (Butler, Hamnett, \& Ramsden, 2013; Wilson $\&$ Bridge, 2019). So this actually forms a vicious circle where wealthy parents cluster in wealthy catchment areas of popular schools and make these schools and areas even more attractive and expensive (Bernelius \& Vilkama, 2019).

\subsection{Parental SES and School Choice Causing Educational Inequality}

High-SES parents can evade school catchment area restrictions by moving into other catchment areas with better schools or by some illicit means like using false addresses (Boterman, 2019; McGinn \& Ben-Porath, 2014). Considering parents' school choosing needs, many countries adopt school choice policies that allow choosing schools across catchment areas, with the hope to promote school quality through competition (Hadderman, 2002; McGinn \& Ben-Porath, 2014). However, such policies have been controversially debated since their implementation. Some argue that they can improve the quality and equity of education, especially by allowing disadvantaged parents to choose schools across districts (Manno, Finn, Chester, Bierlein, \& Gregg, 1998; Viteritti, 2003), but more studies show that school choice policy exacerbates educational inequality because parents of different classes do not have the same ability to choose schools (Cheng, 2002). Parents who have the ability of school choice are highly educated with occupational prestige, compared to lower SES families forced to accept the school catchment assignment (Echols \& Willms, 1992; Willms \& Echols, 1993). Thus, students from high-SES families may benefit more from this education market of school choice (Robert, 2010).

Attitudes towards education also matter towards school choice, albeit restricted by available resources. Middle-class parents are found to regard education as a negotiable system while working-class parents just accept the school arrangement (Webber \& Butler, 2007; Willis, 1977). Lower-class parents may not be aware of the benefits of education, as they have not benefitted much from education themselves. However, Chin and Phillips (2004) argue that parents of different SES all have high educational expectations for children and apply similar parenting strategies, but disadvantaged families are restricted by a lack of resources, which means it is not attitudes but rather attitudes in the context of the range of available options that matters (Boterman, 2019). In summary, different attitudes and abilities between parents of different SES affect children's chances of good schooling.

\subsection{School Access in the Taiwanese Context}

The education system of Taiwan provides a crucial case to explore how urbanisation and parental SES act together predicting unequal school access opportunities. Taiwan has implemented a nine-year, centrally controlled education since 1968. With compulsory education until middle school, the government aims to ensure equal opportunities (Ministry of Education, 2020b). Although from the late 1980 s to the early 1990s, Taiwan relaxed central government control and enhanced the local autonomy of education under the influence of neo-liberal ideology (Mao, 2015). Public middle schools still dominate, with recent statistics showing that $98.2 \%$ of middle schools are public (Ministry of Education, 2020a). Public schools are mainly financed by local governments (L.-J. Chen, 2006). The central government only provides financial subsidies if local educational funds are not up to the national standards, to ensure equal conditions for public 
middle schools in all regions. Such a system would theoretically ensure similar funding and qualities among public schools. Nevertheless, studies show that the disparity in economic development across Taiwan leads to a large financial inequality in education (L.-J. Chen, 2006). Local educational spending in urbanised areas is much higher than in less urbanised areas (L.-J. Chen \& Chen, 2013).

In Taiwan, public middle schools that students attend are determined by the system of catchment areas set up by administrative education authorities (Mao, 2015). Students generally go to the nearest middle school according to their family's residence in the catchment area. But under the pressure of the high school entrance exam, some parents believe that only the informally ranked "superstar schools"-junior high schools with a high percentage of graduates gaining admission to prestigious public senior high schools (Mao, 2015) - will better prepare their children for the entrance exams of elite high schools. Contrasting with some Western cases, these prestigious public schools are generally perceived as higher status schools than private schools (Chu \& Yeh, 1995), which is comparable to the situation in Japan (Aizawa, 2016). So, if there are no such "superstar schools" in a given school catchment area, some may gain access to schools across the catchment boundary by changing their home address (Mao, 2015). As a result, the access opportunity to middle schools of various qualities is unequal in reality. The differences in school popularity lead to fierce competition to gain access to perceived high-quality schools. Such competition requires that parents spend a great deal of energy and resources on choosing schools and deciding where to live, which means middle-class parents with more available resources are more likely to win. This inequality of access to schools is more severe in densely populated areas than in less populated areas (Chang, 2000), from which we can infer that more urbanised areas with large populations have more access to good schools but also more severe competition for entrance.

The unequal access to schooling is reflected in the distribution of SES in our study area (i.e., northern Taiwan): Figure 1 shows that more urbanised centres such as Taipei City contain higher shares of highly educated individuals and shows a variation with urbanised areas as well. Much of this image can be explained by urban areas being the areas where higher-paying jobs cluster, requiring highly educated people, but the image also aligns with the idea that in terms of schooling, some areas are more attractive than others, potentially causing the spatial variation of high-SES individuals. When comparing educational and occupational segregation in our study area with other areas in Taiwan (Table 1), it shows that segregation is on the lower end compared to the rest of Taiwan. In the case of Taiwan, most of the variation in SES is within, rather than between districts. Taipei is comparable to a city like Tokyo in its low level of urban segregation (Maloutas \& Fujita, 2012). The relatively low levels of segregation can be related to Taiwan's relative- ly low income inequality compared to the region. With a disposable household income Gini index of 31.1 in 2010, income inequality is lower than in Mainland China (42.8), Hong Kong (40.7) and Singapore (39.3), and comparable to Japan (31.8) and South Korea (31.4; see Solt, 2020). We aim to examine how, in a situation of relatively low segregation and inequality, families seek educational distinction for their children.

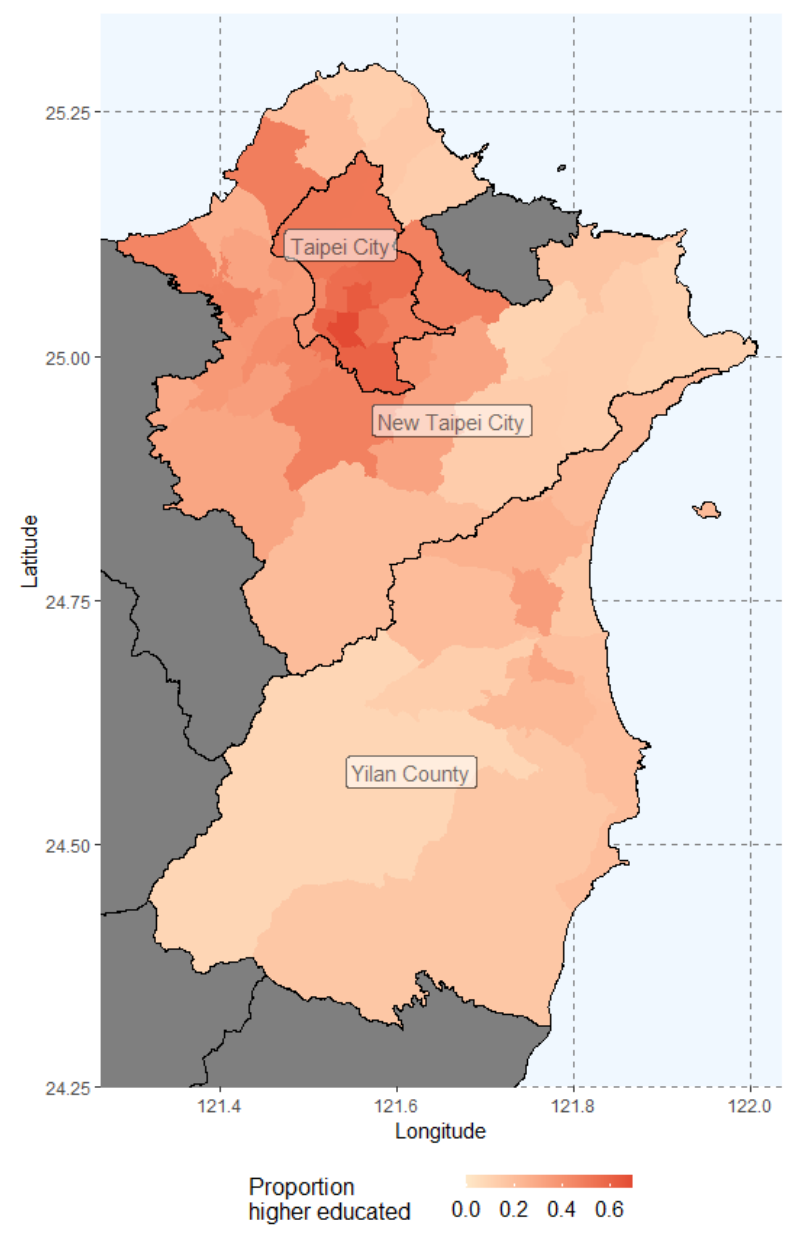

Figure 1. Proportion of higher-educated individuals in northern Taiwan, by township, city, and district. Notes: The map shows the proportions of individuals aged 15 years and over with junior college, university, or higher education in 2010. The spatial scale is townships/cities/districts, which are nested in Taipei City, New Taipei City (which roughly corresponds to Taipei County in our data, which was renamed New Taipei City in 2010), and Yilan County. Source of data: 2010 Population and Housing Census (DGBAS, 2010).

\subsection{Hypotheses}

Previous studies have pointed out that urbanisation and family SES both affect access opportunities to schools. Because high-income schools and high-SES families both cluster in urbanised areas, parents of higher socioeconomic backgrounds have better school 
Table 1. Residential segregation by education and occupation in counties and cities.

\begin{tabular}{lcccc}
\hline & $H^{R}$ education & $R^{R}$ education & $H^{R}$ occupation & $R^{R}$ occupation \\
\hline Hualien County & .054 & .066 & .031 & .038 \\
Yunlin County & .044 & .056 & .028 & .035 \\
Taitung County & .044 & .055 & .022 & .025 \\
Chiayi City/County & .043 & .053 & .044 & .055 \\
Penghu County & .035 & .045 & .019 & .025 \\
Pingtung County & .033 & .040 & .034 & .042 \\
Miaoli County & .033 & .040 & .030 & .036 \\
Tainan City & .031 & .039 & .034 & .042 \\
Nantou County & .029 & .035 & .019 & .022 \\
Taichung City & .028 & .035 & .033 & .041 \\
Hsinchu City/County & .027 & .036 & .036 & .043 \\
Changhua County & .023 & .028 & .028 & .035 \\
Kaohsiung City & .022 & .027 & .028 & .033 \\
Yilan County* & .021 & .026 & .027 & .033 \\
Taipei City* & .019 & .027 & .020 & .024 \\
New Taipei City* & .019 & .023 & .017 & .020 \\
Taoyuan County & .014 & .018 & .017 & .020 \\
Kinmen County & .010 & .012 & .017 & .020 \\
Keelung City & .004 & .005 & .006 & .007 \\
Lienchiang County & .000 & .001 & .009 & .012 \\
\hline
\end{tabular}

Notes: Segregation indices $H^{R}$ and $R^{R}$ stand for the rank-order information theory index and the rank-order variance ratio index, respectively (for more specific descriptions of these measures see Reardon, 2011). Both can be interpreted as proportions of the variation in education and occupation that lies between rather than within townships/cities/districts. Educational segregation is based on four categories: "elementary and lower," "junior high," "senior high and vocational," and "junior college, university and higher." Occupational segregation is based on nine categories: "legislators, senior officials and managers," "professionals," "technicians and associate professionals," "clerical support workers," "service and sales workers," "skilled agricultural, forestry and fishery workers," "craft and related trades workers," "plant and machine operators, and assemblers," and "elementary labourers." The segregation measures for education and occupation use the first and sixth polynomial, respectively. The list is ordered from highest to lowest segregation based on $H^{R}$ education. Source of data: 2010 Population and Housing Census (DGBAS, 2010). * Yilan County, Taipei City, and New Taipei City (Taipei County) are the sample areas.

choices. Based on the previously established connection between these two factors, we formulated the following two hypotheses:

- Hypothesis 1: Students in more urbanised areas have access to (a) higher-income schools and (b) more variation in school average income levels than students in less urbanised areas.

- Hypothesis 2: In more urbanised areas, students with higher family SES have access to higherincome schools than students with lower family SES, but not in less urbanised areas.

\section{Data and Methods}

\subsection{Data}

We used the Taiwan Youth Project, a panel dataset of students and parents from Northern Taiwan, collected since 2000. The original sample consisted of 5,541 students from a 7th and 9th-grade cohort, aged around 13 and 15, respectively. Respondents were sampled from 162 classrooms within 40 schools, within three regions (Taipei City, Taipei County, and Yilan County). We used both student- and parent-reported information, from survey waves 1 and 4 (in wave 4 , students were in the first and final year of high school for the younger and older cohort, respectively). The final sample with all relevant information was 2,893 .

\subsection{Measurements}

Average school income was measured using parental income from survey wave 4 . For the older cohort, household income was measured as a parent-reported continuous variable (0 to 155 in NT\$1,000). For the younger cohort, the measure consists of a student-reported categorical variable. We used the middle of the NT\$10,000 categories as our value. The average school income was measured by taking the average household income for each of the 146 schools students attended in wave 4 . Descriptive statistics are available in Table 2.

The level of urbanisation of the respondents' place of residence was measured with the following categories: core city, general city, emerging town, and general and ageing township. This classification was specifically designed to best capture urbanisation in Taiwan (Hou, Tu, Liao, Yung, \& Chang, 2008). The classification 
Table 2. Descriptive statistics ( $N=2,893$ ).

\begin{tabular}{|c|c|c|c|c|}
\hline Variable & Mean & SD & Min. & Max. \\
\hline Average school income & 57.48 & 19.01 & 15 & 125 \\
\hline Household income & 59.66 & 34.31 & 0 & 155 \\
\hline Parental education & 3.45 & 1.63 & 1 & 7 \\
\hline \multirow[t]{2}{*}{ Years lived in the neighbourhood } & 8.73 & 7.34 & 0 & 18 \\
\hline & Prop. & & & \\
\hline Urbanisation: Core city & .48 & & & \\
\hline -General city & .31 & & & \\
\hline -Emerging town & .12 & & & \\
\hline -General and ageing township & .08 & & & \\
\hline Female & .50 & & & \\
\hline 9th-grade cohort & .44 & & & \\
\hline Ethnicity: Minnan & .78 & & & \\
\hline -Hakka & .07 & & & \\
\hline -Mainland & .13 & & & \\
\hline -Aboriginal/other & .02 & & & \\
\hline
\end{tabular}

was calculated using Ward's minimum variance method, including six categories that capture urbanisation in Taiwan: the percentage of service industry population, the percentage of industry population, the percentage of 15 to 64 years old population, the percentage of above 65 years old, the percentage of the above population holding a college degree, and population density (Hou et al., 2008).

Household income was measured in wave 1 as a parent-reported continuous variable (0 to 155 in NT\$1,000). In the few cases parent-reported income was missing, we substituted with a categorical studentreported household income. We used the middle of the NT\$10,000 categories as our value.

Parental education was measured continuously as parents' highest level of education in the following order: elementary school, middle school, vocational high school, academic high school, junior college, university, and graduate school.

We included four control variables: sex ( $0=$ male; $1=$ female $)$ and cohort ( $0=7$ th grade; $1=9$ th grade $)$. Ethnicity has been shown to play a role in education in Taiwan, where especially Mainlanders have an advantage over other groups (Chiang \& Park, 2015; Jao \& McKeever, 2006). Ethnicity was measured as father's ethnic background ( 1 = Minnan; 2 = Hakka; 3 = Mainlander; 4 = Aboriginal/other). Finally, because the residential environment might be more important when students have lived there longer (Nieuwenhuis, Yu, Branje, Meeus, \& Hooimeijer, 2016), we included the years someone lived in his/her neighbourhood in wave 4.

\subsection{Analyses}

To test our hypotheses, we examined the relationship between urbanisation, parental education, household income in wave 1 (age 13/15) and average school income in wave 4 (age 16/18) using regression analysis. Because respondents who attend the same school are not independent of each other, we clustered standard errors in schools, to avoid underestimating $p$-values. We present three models, the first including all relevant covariates, and the second and third including an interaction between urbanisation and household income and parental education, respectively. Additionally, we calculated the marginal effects of parental education and household income for the different levels of urbanisation.

To calculate average school income, we only used schools that had 10 or more students from the sample enrolled to ensure the precision of the estimate. Additional robustness checks using only schools with 20 or more students show the same results (available on request), further indicating good precision. Because of this limit, we had to omit 880 respondents from the analyses. Further attrition between waves reduced our sample from the original 5,541 to 2,893 . To test whether attrition could affect our outcomes, we performed several t-tests to examine whether the probability of data missingness is associated with school average income. We test how different the used sample is from the sample with missing values, on several key variables (Allison, 2002). The tests showed that parental education ( $t=.54$, $\mathrm{df}=5,403, \mathrm{p}=.591)$ and urbanisation ( $\mathrm{t}=-1.09$, $\mathrm{df}=5,539, \mathrm{p}=.274$ ) are missing at random. Respondents coming from households with lower household income are more likely to be missing ( $t=3.24$, df $=5,368$, $p=.001)$. The higher attrition from lower-income households could potentially influence our results.

\section{Results}

Table 3 shows the descriptive results of average income levels in schools by level of urbanisation. More urbanised 
Table 3. Descriptive statistics of average school income by level of urbanisation.

\begin{tabular}{llrrr}
\hline & Mean & SD & Min. & Max. \\
\hline Core city & 63.11 & 12.45 & 43.74 & 87.95 \\
General city & 59.65 & 9.44 & 48.40 & 77.22 \\
Emerging town & 46.87 & 4.80 & 39.59 & 52.99 \\
General and aging township & 42.93 & 5.99 & 34.00 & 49.01 \\
\hline
\end{tabular}

areas have higher average and maximum levels of school income and also a wider range of school income than less urbanised areas, in line with hypothesis 1 . Next, we tested how urbanisation, family SES, and average school income are related (Table 4). Model 1 also shows that students from less urbanised areas are more likely to attend lower-income schools, which is in line with hypothesis $1 \mathrm{a}$ and the descriptive results from Table 3. Besides, children from higher-educated and higherincome parents are more likely to attend higher-income schools. Models 2 and 3 present the interaction between urbanisation and household income and parental education, respectively. The models show, in line with hypothesis 2, that the relationship between parental income and education and school income levels is stronger for children in the areas with high levels of urbanisation (core and general city), and weaker in emerging towns and townships. The likelihood ratio tests show that both models are an improvement over the models without interactions. Marginal effects show that both household income and parental education only have a significant effect in the most urbanised areas (Income: core city: $b=.11 ;$ s.e. $=.02 ; p<.001$; general city: $b=.06$, s.e. $=.02, p=002$; emerging town: $b=.04$, s.e. $=.02$, $\mathrm{p}=.116$; township: $\mathrm{b}=.04$, s.e. $=.04, \mathrm{p}=.276$; Education: core city: $b=2.90$, s.e. $=.48, p<.001$; general city: $b=1.59$, s.e. $=.57, p=.006$; emerging town: $\mathrm{b}=-1.19$, s.e. $=.50, \mathrm{p}=.019$, township: $\mathrm{b}=-.52$, s.e. $=.73, p=.475)$. The time during which respondents lived in their neighbourhood did not change the relationship between urbanisation, parental SES, and attending higher-income schools. Finally, control variables gender,

Table 4. Regression results for school income level $(N=2,893)$.

\begin{tabular}{|c|c|c|c|c|c|c|c|c|c|}
\hline & \multicolumn{3}{|c|}{ Model 1} & \multicolumn{3}{|c|}{ Model 2} & \multicolumn{3}{|c|}{ Model 3} \\
\hline & B & SE & $\mathrm{p}$ & B & SE & $\mathrm{p}$ & B & SE & $\mathrm{p}$ \\
\hline \multicolumn{10}{|l|}{ Urbanisation (ref. Core city) } \\
\hline (2) General city & -3.47 & 2.07 & .095 & -.30 & 2.54 & .905 & 1.32 & 3.11 & .672 \\
\hline (3) Emerging town & -9.15 & 2.32 & $<.001$ & -5.08 & 2.84 & .076 & -3.99 & 3.22 & .218 \\
\hline (4) General and aging township & -14.52 & 2.71 & $<.001$ & -10.75 & 3.22 & .001 & -7.52 & 3.80 & .049 \\
\hline Household income (in NT\$1,000) & .08 & .01 & $<.001$ & .11 & .02 & $<.001$ & .08 & .01 & $<.001$ \\
\hline Parental education & 2.17 & .35 & $<.001$ & 2.12 & .34 & $<.001$ & 2.90 & .48 & $<.001$ \\
\hline \multicolumn{10}{|c|}{ Interaction household income with urbanisation } \\
\hline (2) & & & & -.05 & .03 & .058 & & & \\
\hline (3) & & & & -.08 & .03 & .015 & & & \\
\hline (4) & & & & -.07 & .04 & .085 & & & \\
\hline \multicolumn{10}{|c|}{ Interaction parental education with urbanisation } \\
\hline$(2)$ & & & & & & & -1.31 & .69 & .059 \\
\hline (3) & & & & & & & -1.70 & .72 & .019 \\
\hline (4) & & & & & & & -2.37 & .92 & .011 \\
\hline Female & 1.69 & 1.37 & .220 & 1.63 & 1.36 & .232 & 1.62 & 1.35 & .232 \\
\hline 9th grade cohort & 3.18 & 3.68 & .389 & 3.15 & 3.66 & .391 & 2.94 & 3.67 & .425 \\
\hline \multicolumn{10}{|l|}{ Ethnicity (ref. Minnan) } \\
\hline -Hakka & .60 & 1.38 & .665 & .64 & 1.38 & .643 & .62 & 1.37 & .649 \\
\hline -Mainland & 2.44 & 1.20 & .044 & 2.39 & 1.20 & .048 & 2.28 & 1.19 & .058 \\
\hline -Aboriginal/other & -.93 & 2.24 & .678 & -.98 & 2.22 & .659 & -.99 & 2.18 & .652 \\
\hline Years lived in the neighborhood & .26 & .14 & .071 & .26 & .14 & .072 & .27 & .14 & .060 \\
\hline Intercept & 43.53 & 2.72 & $<.001$ & 41.91 & 2.81 & $<.001$ & 40.99 & 2.96 & $<.001$ \\
\hline$R^{2}$ & .2276 & & & .2305 & & & .2317 & & \\
\hline $\begin{array}{l}\text { Likelihood ratio test with } \\
\text { Model } 1\left(\mathrm{chi}^{2}(\mathrm{df})\right)\end{array}$ & & & & $10.87(3)$ & .012 & $15.45(3)$ & .002 & & \\
\hline
\end{tabular}


cohort, and ethnicity did not play a role in predicting average income in schools. Only Mainlanders seemed to end up on higher-income schools, however, because the significance level hovered around $p=.05$, depending on the model, this evidence is very weak.

\section{Conclusion}

School inequality has a crucial influence on educational outcomes and life opportunities. This article aims to identify how urbanisation and family SES are related to children's access opportunities to good schools. Our results show that both factors impact access to schools and that the two are intertwined. Students with higher family SES backgrounds from more urbanised areas have more opportunities to access higher-income schools. But this relation between family SES and school inequality is only prominent in the most urbanised areas and does not appear in less urbanised areas. It suggests that in the most urbanised areas, higher income and higher educated parents enjoy more school choices, like high-income public schools or private schools. They may have more economic resources and knowledge to choose good schools despite school catchment area limitations because they can either afford addresses in an affluent catchment with high-quality schools or put more effort into children's educational planning and school choice. However, when it comes to less urbanised areas like towns or townships, schools are generally poorer and fewer, so the relation between parental SES and school income level is not present, which underlines the socio-spatial inequality of school distribution. This also adds to the understanding that school quality is a pathway through which residential segregation can reproduce educational inequality (Galster, 2011; Nieuwenhuis \& Hooimeijer, 2016; Nieuwenhuis, Hooimeijer, \& Meeus, 2015).

The Taiwanese case in this article verifies the relation between socio-spatial inequality and school inequality, and the relation between family SES and school inequality in previous studies. Furthermore, we extend this literature by demonstrating how urbanisation and family SES interact together when predicting children's school access opportunities. When a place is more urbanised, there will be more high-income jobs and economic resources, which will attract higher-educated parents. On the other hand, such places will be difficult to afford for low-SES parents, thus fostering residential segregation. Together with school segregation, such socio-spatial inequality exacerbates educational inequality. Because levels of residential segregation in our study areas are lower than in many other counties and cities in Taiwan, school quality may be more stratified by family SES in other areas. Placing Taiwan in the East Asian region is more difficult: Taiwan's and South Korea's educational inequality are decreasing, Japan's and culturally similar Mainland China's educational inequality are increasing (Hannum, Ishida, Park, \& Tam, 2019). How the differ- ences in residential inequality in these regions relate to changes in the educational climate still needs more rigorous and comparative study.

We identified three limitations to this study which can contribute to the development of future studies on this topic. First, it is unclear if our findings are generalisable to areas with free school choice. In many European countries, school choice policy has been implemented, but its impact on educational equity is controversial (Cheng, 2002; Viteritti, 2003; Willms \& Echols, 1993). In the United States, many publicly funded but privately managed charter schools have no eligibility restrictions. While charter schools give some minority students extra school choices, these schools may draw away funding from public schools, but have uncertain educational outcomes (Bifulco \& Ladd, 2006) and even increased school segregation (Rotberg, 2019). The effect of these school choice policies on educational equity also depends on the local education system and the perception of parents of public vs. private schools (the former being considered higher status in Taiwan, but not necessarily in other places), so more research is needed for accurate comparisons. It is reasonable to speculate that high-SES parents will always be able to access better schools by calling on the economic and cultural resources they have. In cases with school district restrictions, they can purchase houses in better school catchment areas to qualify for admission. With a free school choice policy, they can choose more expensive and competitive schools, because they can afford the cost of commuting long distances to other school districts. Besides, higher SES parents can afford supplementary education, even further exacerbating educational stratification. While lowSES parents, on the one hand, may be able to avoid bad schools within their catchment when there are no school district restrictions on the other hand, they may still only be able to afford the closest school regardless of its quality, as they have fewer resources for commuting. Furthermore, they may not be as aware as higherSES parents of the importance of and diversity in school quality. Thus, whether the effects of parental SES and urbanisation are different under the two, school choice systems may await future comparative studies.

Second, we only had access to data about average parental income for schools, which we used as a proxy for school quality. With this proxy, we refer to the social constructive process describing how parental perceptions of school quality is reflected through wealthier parents being able to put more resources into getting into these perceived good schools, resulting in a clustering of a higher-income population in perceived higher-quality schools. Of course, this proxy is not perfect, and future studies may improve on this by using more comprehensive measures of school wealth and quality, which could include school funding and donations, teacher-student ratio, or measures for teacher quality.

Third, the informed assumption of a positive correlation between school wealth and quality still needs 
further examination. What are the mechanisms and conditions for this relation? High-SES households can potentially bring in more donations that contribute to school quality, as well as social and cultural capital that help students' development and chances. Future research into this topic may want to study indicators of school wealth and school quality simultaneously, to understand more specifically what parents base their school decisions on.

In conclusion, even when school populations are mostly reflections of the catchment area population, it is the high-SES parents who are best able to avoid catchment areas. Taiwan's uniform public school funding and catchment area limitations still leave room for unequal school access opportunities. For educational policymakers, this article, combined with those about school choice policies, suggest that the educational outcomes of school choice policy and catchment areas are not clear-cut, and are strongly linked to geography. Where people live, both in terms of between different cities, as within cities, is associated with the opportunity structure faced by parents, with some parents being better able to deal with this structure than others.

\section{Acknowledgments}

The authors would like to thank Yi-Lin Chiang and ShunYuan Lo for help with data-related questions.

\section{Conflict of Interests}

The authors declare no conflict of interests.

\section{References}

Aizawa, S. (2016). A comparative sociological study of Japanese and Taiwanese upper secondary education. Educational Studies in Japan, 10, 33-48.

Allison, P. (2002). Missing data. Thousand Oaks, CA: Sage.

Alon, S. (2009). The evolution of class inequality in higher education: Competition, exclusion, and adaptation. American Sociological Review, 74(5), 731-755.

Ball, S. J. (2002). Class strategies and the education market. London: Routledge Falmer.

Bernelius, V., \& Vaattovaara, M. (2016). Choice and segregation in the "most egalitarian" schools: Cumulative decline in urban schools and neighbourhoods of Helsinki, Finland. Urban Studies, 53(15), 3155-3171.

Bernelius, V., \& Vilkama, K. (2019). Pupils on the move: School catchment area segregation and residential mobility of urban families. Urban Studies, 56(15), 3095-3116.

Bifulco, R., \& Ladd, H. F. (2006). The impacts of charter schools on student achievement: Evidence from North Carolina. Education Finance and Policy, 1(1), 50-90.

Boterman, W. R. (2019). The role of geography in school segregation in the free parental choice context of
Dutch cities. Urban Studies, 56(15), 3074-3094.

Bourdieu, P. (1977). Cultural reproduction and social reproduction. In J. Karabeland \& A. H. Halsey (Eds.), Power and ideology in education (pp. 487-511). New York, NY: Oxford University Press.

Broccolichi, S., \& van Zanten, A. (2000). School competition and pupil flight in the urban periphery. Journal of Education Policy, 15(1), 51-60.

Butler, T., Hamnett, C., \& Ramsden, M. J. (2013). Gentrification, education and exclusionary displacement in East London. International Journal of Urban and Regional Research, 37(2), 556-575.

Butler, T., \& van Zanten, A. (2007). School choice: A European perspective. Journal of Education Policy, 22(1), $1-5$.

Chang, B. H. (2000). The factors influencing the school choice of parents. In S. W. Yang (Ed.), School choice of parents (pp. 95-250). Taipei: Shining Culture Publishing Co.

Cheadle, J. E., \& Amato, P. R. (2011). A quantitative assessment of Lareau's qualitative conclusions about class, race, and parenting. Journal of Family Issues, 32(5), 679-706.

Chen, L.-J. (1993). Guómín jiàoyù jīngfèi fēnpèi jīhuì gōngpíng zhī yánjiū: Yǐ xiàn shì cáizhèng zhuàngkuàng kăoliáng [Study on the fairness of opportunity in the allocation of national education funding: Considering the financial situation of cities and counties]. Jiàoyù xué kān, 10, 225-259.

Chen, L.-J. (2006). Cóng gōngpíng xìng mài xiàng shì zú xìng: Wǒguó guómín jiàoyù zīyuán fēnpèi zhèngcè de xiànkuàng yǔ zhănwàng [From equity to adequacy: The present and prospect of school resources allocation policy in Taiwan]. Jiàoyù zhèngcè lùntán, 9(4), 101-118.

Chen, L.-J., \& Chen, M. Y. (2013). Wǒguó jiàoyù cáizhèng zhèngcè zhī biàngé yǔ zhănwàng [The reforms and prospects of Taiwan's education finance policy]. Táiwān jiàoyù, 6, 2-12.

Chen, L.-J., \& Chen, T. S. (2009). Dìfāng zhèngfǔ cáizhèng nénglì xìng jiàoyù jīngfèi guān xì zhī tàn jiū: Cáizhèng zhōng xìng guān diăn [An inquiry into the relationship between local fiscal capacity and education expenditure: A fiscal neutrality perspective]. In Difānng jiàoyù fāzhăn yánjiū [A study of the development of local education] (pp. 28-53). Taipei: Higher Education and Culture Enterprise Co.

Chen, Y. G. (2001). Táiwān dìqū gāozhōng/jì zhí fèn liú yǔ jiàoyù jīhuì bù jūnděng xìng zhī biànqiān [The division of senior high school/vocational school and the change of the inequality in education opportunities in Taiwan]. Bulletin of Educational Research, 7(47), 253-282.

Cheng, X. (2002). "Zé xiào" zhèngcè duì jiàoyù jīhuì jūnděng de yǐngxiǎng: Zhōngguó yǔ ōuměi guójiā de bijjiào [The effects of "school-choosing" policy on the equality of educational opportunity]. Journal of Jiangsu Institute of Education, 18(5). 
Chiang, Y.-L., \& Park, H. (2015). Do grandparents matter? A multigenerational perspective on educational attainment in Taiwan. Social Science Research, 51, 163-173.

Chin, T., \& Phillips, M. (2004). Social reproduction and child-rearing practices: Social class, children's agency, and the summer activity gap. Sociology of Education, 77(3), 185-210.

Chu, C. C., \& Yeh, C. (1995). Taiwan's private education. Chinese Education \& Society, 28(4), 66-96.

Condron, D. J., \& Roscigno, V. J. (2003). Disparities within: Unequal spending and achievement in an urban school district. Sociology of Education, 76(1), 18-36.

De la Fuente, H., Rojas, C., Salado, M. J., Carrasco, J. A., \& Neutens, T. (2013). Socio-spatial inequality in education facilities in the Concepción metropolitan area (Chile). Current Urban Studies, 1(4), 117-129.

DGBAS. (2010). 2010 Population and housing census. Directorate General of Budget, Accounting and Statistics. Retrieved from https://census.dgbas.gov.tw/ PHC2010/english/rehome.htm

Downey, D. B., \& Condron, D. J. (2016). Fifty years since the Coleman report: Rethinking the relationship between schools and inequality. Sociology of Education, 89(3), 207-220.

Echols, F., \& Willms, J. D. (1992). Alert and inert clients: The Scottish experience of parental choice of schools. Economics of Education Review, 11(4), 339-350.

Elliott, M. (1998). School finance and opportunities to learn: Does money well spent enhance students' achievement? Sociology of Education, 71(3), 223-245.

Frankenberg, E. (2013). The role of residential segregation in contemporary school segregation. Education and Urban Society, 45(5), 548-570.

Galster, G. C. (2011). The mechanism(s) of neighbourhood effects: Theory, evidence, and policy implications. In M. van Ham, D. Manley, N. Bailey, L. Simpson, \& D. Maclennan (Eds.), Neighbourhood effects research: New perspectives (pp. 23-56). Dordrecht: Springer.

Greenwald, R., Hedges, L. V., \& Laine, R. D. (1996). The effect of school resources on student achievement. Review of Educational Research, 66(3), 361-396.

Hacker, S. R., Klaesson, J., Pettersson, L., \& Sjölander, P. (2013). Regional economic concentration and growth. In J. Klaesson, B. Johansson, \& C. Karlsson (Eds.), Metropolitan regions (pp. 117-139). Berlin: Springer.

Hadderman, M. (2002). Charter schools: Trends and issues (ERIC Document Reproduction Service No. ED472997). Washington, DC: Office of Educational Research and Improvement.

Hannum, E., Ishida, H., Park, H., \& Tam, T. (2019). Education in East Asian societies: Postwar expansion and the evolution of inequality. Annual Review of Sociology, 45, 625-647.

Hochschild, J., \& Scovronick, N. (2003). The American dream and the public schools. New York, NY: Oxford University Press.

Hou, P.-C., Tu, S.-H., Liao, P., Yung, Y.-T., \& Chang, Y.-H. (2008). Táiwān xiāngzhèn shì qū lèixíng zhī yánjiū táiwān shèhuì biànqiān jīběn diàochá dì wǔ qī jì huà zhī chōuyàng fēn céng xiàoguǒ fēnxī [The typology of townships in Taiwan: The analysis of sampling stratification of the 2005-2006 Taiwan social change survey]. Survey Research-Method and Application, 23, 7-32.

Jao, J.-C., \& McKeever, M. (2006). Ethnic inequalities and educational attainment in Taiwan. Sociology of Education, 79(2), 131-152.

Kozol, J. (1991). Savage inequalities. New York, NY: Crown.

Lareau, A. (1987). Social class differences in familyschool relationships: The importance of cultural capital. Sociology of Education, 60(2), 73-85.

Lichter, D. T., \& Brown, D. L. (2011). Rural America in an urban society: Changing spatial and social boundaries. Annual Review of Sociology, 37(1), 565-592.

Lichter, D. T., Cornwell, G. T., \& Eggebeen, D. J. (1993). Harvesting human capital: Family structure and education among rural youth. Rural Sociology, 58(1), 53-75.

Logan, J. R., Minca, E., \& Adar, S. (2012). The geography of inequality: Why separate means unequal in American public schools. Sociology of Education, 85(3), 287-301.

Lubienski, C. (2005). Public schools in marketized environments: Shifting incentives and unintended consequences of competition-based educational reforms. American Journal of Education, 111(4), 464-486.

Maloutas, T., \& Fujita, K. (2012). Residential segregation in comparative perspective. Burlington, NJ: Ashgate.

Manno, B. V., Finn, C. E., Jr., Bierlein, L., \& Gregg, V. (1998). How charter schools are different. Phi Delta Kappan, 79(7), 489-500.

Mao, C.-J. (2015). Choice as a global language in local practice: A mixed model of school choice in Taiwan. The International Education Journal, 14(2). Retrieve from https://openjournals.library.sydney. edu.au/index.php/IEJ/article/view/9307/9209

Marjoribanks, K. (1979). Families and their learning environments. London: Routledge and Kegan Paul.

Mayet, G. (1996). Admissions to schools: A study of local education authorities. In R. Glatter, P. Woods, \& C. Bagley (Eds.), Choice and diversity in schooling (pp. 166-177). London: Routledge.

McGinn, K. C., \& Ben-Porath, S. (2014). Parental engagement through school choice: Some reasons for caution. Theory and Research in Education, 12(2), 172-192.

Ministry of Education. (2020a). Education statistics inquiry network-number of existing schools. Ministry of Education. Retrieved from http://stats.moe.gov. tw/qframe.aspx?qno=MQAxAA2

Ministry of Education. (2020b). Comprehensive plan- 
ning department-Introduction to the current situation of education in Taiwan. Ministry of Education. Retrieved from https://depart.moe.edu.tw/ED2100/ Content_List.aspx?n=09E8A4EDA021E1E5

Nieuwenhuis, J. (2018). The interaction between school poverty and agreeableness in predicting educational attainment. Personality and Individual Differences, $127,85-88$.

Nieuwenhuis, J. (2020). Neighborhood social capital and adolescents' individual health development. Social Science \& Medicine, 265. https://doi.org/10.1016/ j.socscimed.2020.113417

Nieuwenhuis, J., \& Hooimeijer, P. (2016). The association between neighbourhoods and educational achievement, a systematic review and meta-analysis. Journal of Housing and the Built Environment, 31(2), 321-347.

Nieuwenhuis, J., Hooimeijer, P., \& Meeus, W. (2015). Neighbourhood effects on educational attainment of adolescents, buffered by personality and educational commitment. Social Science Research, 50, 100-109.

Nieuwenhuis, J., Hooimeijer, P., van Dorsselaer, S., \& Vollebergh, W. (2013). Neighbourhood effects on school achievement: The mediating effect of parenting and problematic behaviour? Environment and Planning A, 45(9), 2135-2153.

Nieuwenhuis, J., Tammaru, T., van Ham, M., Hedman, L., \& Manley, D. (2020). Does segregation reduce sociospatial mobility? Evidence from four European countries with different inequality and segregation contexts. Urban Studies, 57(1), 176-197.

Nieuwenhuis, J., Yu, R., Branje, S., Meeus, W., \& Hooimeijer, P. (2016). Neighbourhood poverty, work commitment and unemployment in early adulthood: A longitudinal study into the moderating effect of personality. PLoS ONE, 11(12). https://psycnet.apa.org/doi/ 10.1371/journal.pone.0167830

Noreisch, K. (2007). School catchment area evasion: The case of Berlin, Germany. Journal of Education Policy, 22(1), 69-90.

Oberti, M. (2007). Social and school differentiation in urban space: Inequalities and local configurations. Environment and Planning A, 39(1), 208-227.

Oberti, M., \& Savina, Y. (2019). Urban and school segregation in Paris: The complexity of contextual effects on school achievement: The case of middle schools in the Paris metropolitan area. Urban Studies, 56(15), 3117-3142.

Owens, A., \& Candipan, J. (2019). Social and spatial inequalities of educational opportunity: A portrait of schools serving high- and low-income neighbourhoods in US metropolitan areas. Urban Studies, 56(15), 3178-3197.

Parsons, E., Chalkley, B., \& Jones, A. (2000). School catchments and pupil movements: A case study in parental choice. Educational Studies, 26(1), 33-48.

Perry, L., \& McConney, A. (2010). School socio-economic composition and student outcomes in Australia:
Implications for educational policy. Australian Journal of Education, 54(1), 72-85.

Portes, A., \& MacLeod, D. (1996). Educational progress of children of immigrants: The roles of class, ethnicity, and school context. Sociology of Education, 69(4), 255-275.

Reardon, S. F. (2011). Measures of income segregation (CEPA Working Paper). Palo Alto, CA: Stanford University, Center for Education Policy Analysis. Retrieved from http://cepa.stanford.edu/content/ measures-income-segregation

Robert, P. (2010). Social origin, school choice, and student performance. Educational Research and Evaluation, 16(2), 107-129.

Roscigno, V. J., Tomaskovic-Devey, D., \& Crowley, M. (2006). Education and the inequalities of place. Social Forces, 84(4), 2121-2145.

Rotberg, I. C. (2019). Backtalk: The social costs of proliferating charter schools. Phi Delta Kappan, 100(7), 80-80.

Rowe, E. E., \& Lubienski, C. (2017). Shopping for schools or shopping for peers: Public schools and catchment area segregation. Journal of Education Policy, 32(3), 340-356.

Slavin, R. E. (1999). How can funding equity ensure enhanced achievement? Journal of Education Finance, 24, 519-528.

Solt, F. (2020). Measuring income inequality across countries and over time: The standardized world income inequality database. Social Science Quarterly, 101(3), 1183-1199.

Tam, T., \& Jiang, J. (2014). The making of higher education inequality: How do mechanisms and pathways depend on competition? American Sociological Review, 79(4), 807-816.

Taylor, C., \& Gorard, S. (2001). The role of residence in school segregation: Placing the impact of parental choice in perspective. Environment and Planning $A$, 33(10), 1829-1852.

Viteritti, J. P. (2003). Defining equity: Politics, markets, and public policy. In A Wolfe (Ed.), School choice: The moral debate (pp. 13-30). Princeton, NJ: Princeton University Press.

Votruba-Drzal, E. (2003). Income changes and cognitive stimulation in young children's home learning environments. Journal of Marriage and Family, 65(2), 341-355.

Waslander, S., \& Thrupp, M. (1995). Choice, competition and segregation: An empirical analysis of a New Zealand secondary school market, 1990-93. Journal of Education Policy, 10(1), 1-26.

Webber, R., \& Butler, T. (2007). Classifying pupils by where they live: How well does this predict variations in their GCSE results? Urban Studies, 44(7), 1229-1253.

Wen, H., Xiao, Y., \& Zhang, L. (2017). School district, education quality, and housing price: Evidence from a natural experiment in Hangzhou, China. Cities, 66, 72-80. 
Wenglinsky, H. (1997). How money matters: The effect of school district spending on academic achievement. Sociology of Education, 70(3). https://doi.org/ $10.2307 / 2673210$

Willis, P. (1977). Learning to labour. Aldershot: Gower.

Willms, J. D., \& Echols, F. H. (1993). The Scottish experience of parental school choice. In E. Rasell \& R. Rothstein (Eds.), School choice: Examining the evidence. Washington, DC: Economic Policy Institute.
Wilson, D., \& Bridge, G. (2019). School choice and the city: Geographies of allocation and segregation. Urban Studies, 56(15), 3198-3215.

$\mathrm{Wu}, \mathrm{X}$. (2012). School choice with Chinese characteristics. Comparative Education, 48(3), 347-366.

Yang, J., Huang, X., \& Liu, X. (2014). An analysis of education inequality in China. International Journal of Educational Development, 37, 2-10.

\section{About the Authors}

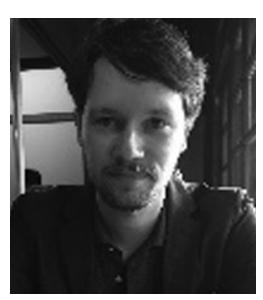

Jaap Nieuwenhuis is Associate Professor at the Department of Sociology at Zhejiang University, China. His major research interests include understanding whether and how neighbourhood and school characteristics influence adolescents' developmental and educational outcomes. Currently, he is working on social networks and social capital in school contexts.

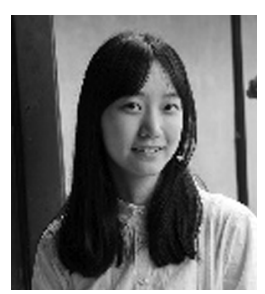

Jiayi Xu is a master's student at the Department of Sociology at Zhejiang University, China. Her main research interests are political sociology and urban sociology. Her undergraduate thesis was about online social movements. Now she is working on gardening history in urban cities and hopes to write about professional gardeners and landscape designers. 